\title{
Influence of Ni (II) Oxime Complex Coupled with the Combination of Diverse Sized ZnO Nanoparticles on Photovoltaic Performance
}

\author{
Prashanth Kumar P.N. ${ }^{1}$, Sajan Ponnappa Chimmikuttanda ${ }^{2 *}$, Ravi Hethegowdanahally
}

Rajegowda $^{3}$, Amol Naik ${ }^{2}$, Maxwell Selase Akple ${ }^{4}$

${ }^{1}$ Kuvempu University, Jnanasahyadri, Shankaragatta, Karnataka-577451.

${ }^{2}$ Chemistry R and D, VerdeEn Chemicals Pvt. Ltd, D-11, UPSIDC Industrial Area, MasoorieGulawati Road, Hapur District, Uttar Pradesh, India-201015

${ }^{3}$ Research Center \& P.G. Department of Physics, Bharathi College, Bharathinagara, Mandya, Karnataka, India.

4. Mechanical Engineering Department, Ho Technical University, P.O. Box HP 217, Ho, Ghana

\section{ARTICLE INFO}

Keywords:

$\mathrm{ZnO}$ particles

$\mathrm{ZnO}$ films

$\mathrm{Ni}$ (II) oxime complex

Photovoltaic

Performance

\begin{abstract}
The one side selective synthesis of quinoline carboxylic acid oxime complex was carried out successfully. The as-prepared quinoline carboxylic acid oxime complex was complexed with nickel (II) salts to form nickel (II) oxime complex. These complexes were further adsorbed onto $\mathrm{ZnO}$ films containing $\mathrm{ZnO}$ nanoparticles of various sizes. $\mathrm{ZnO}$ films containing a diverse proportion of $\mathrm{ZnO}$ nanoparticles were investigated to enhance the photovoltaic efficiency of the dye-sensitized solar cell. The as-synthesized complex was characterized by scanning electron microscopy (SEM), Ultra violet visible spectroscopy (UV-vis), Fourier Transform Infrared Spectroscopy (FT-IR) spectroscopy, ${ }^{1}$ Hydrogen Nuclear magnetic resonance spectroscopy (1HNMR), Liquid chromatography coupled with mass spectrometry (LC-MR), BrunauerEmmett-Teller (BET), and Attenuated total reflection Infra-red spectroscopy (ATR-IR). The combination of large and small $\mathrm{ZnO}$ nanoparticles has significantly improves the photovoltaic efficiency. The optimum mixing ratio for the best performance $(0.127 \%)$ of a dyesensitized solar cell is achieved by mixing the small: large $\mathrm{ZnO}$ particles in a ratio 60:40. The increased efficiency is due to the harvesting of light caused by scattering effect from larger sized $\mathrm{ZnO}$ particles. The $\mathrm{ZnO}$ layer consisting of smaller particles which are very next to the $\mathrm{ZnO}$ bigger particles makes a good electronic contact between film electrode and the Indium-doped tin oxide glass substrate resulting in the increases in the dye molecules adsorption. The over-layered, large-sized $\mathrm{ZnO}$ particles enhance the light-harvesting by light scattering effect. Compared to the other mixtures of $\mathrm{ZnO}$ films, there is a decrease in the photovoltaic performance of the solar cell when $\mathrm{ZnO}$ particles (small and large in a ratio 1:1) were adsorbed onto the $\mathrm{Ni}$ (II) oxime complex, which are caused due to the decrease in the surface area and dye aggregation.
\end{abstract}

\section{Introduction}

The boom in technology development has led to a swift growth in the industrialization and urbanization which require a lot of energy for its sustenance. Currently, the developing and the underdeveloped nations are still dependent on the non-renewable source of energy which

\footnotetext{
* Corresponding Author E-Mail Address: sajan.saj@ rediff.com 
is limited. The overexploitation of these resources will lead to their depletion which takes several million years to recover. To conserve the non-renewable source of energy we need to opt for the renewable energy source. Among the renewable source of energy solar energy is an eco-friendly pioneer form. However, to absorb the solar light and heat and for converting and storing them in the form of energy we need solar cells. The triumph in the efficiency of power conversion has inspired and has brought much self-reliance in the knack of DyeSensitized Solar Cells (DSSCs). Developing of DSSCs having high efficiency will confront the high costs of commercially accessible solar cells which are based on sensitizers adhered to the metal oxide films (Grätzel, 2001; Habibzadeh et al., 2010; Jo et al., 2019; Nazeeruddin et al., 1993; O'Reagen \& Gratzel, 1991; Park et al., 2019; Wen et al., 2019). However, in DSSCs, there is still substantial recombination of electrons and holes. These recombinations result from the thin coating of $\mathrm{ZnO}(6 \mu \mathrm{m})$ ensuing in the lessening of energy conversion and an increase in energy loss (Chappel et al., 2005). These recombinations are initiated predominately from the thinning of the $\mathrm{ZnO}$ layer onto $\mathrm{ZnO}$ nanocrystallite surface. Researchers have come forward and have evaluated this issue by raising the thickness of photo-electrode film for photovoltaic studies. A variety of techniques has been explored to succeed over the electron and hole recombination. One such method is the application of onedimensional nanostructures that offer a direct corridor for electron transport or by developing composite materials/hybrid material along with semiconducting particle which boasts favourable energies. Besides, efforts have been made to curtail the recombination of electron and hole rate using core-shell structures with oxide coating (Chen et al., 2001; Kumara et al., 2003; Makhonina et al., 2019; Palomares et al., 2002; Sant \& Kamat, 2002; Tennakone et al., 1999; Zhu et al., 2019). In DSSCs photons are brought together by the sensitizer, which is placed onto the plane of $\mathrm{ZnO}$ film. Consequently, in a DSSC the coefficient of the photoabsorption ability of the $\mathrm{ZnO}$ film along with the sensitizers is pretty lesser compared to the semiconductor film of a solar cell. In DSSCs the higher absorption coefficient from a $\mathrm{ZnO}$ film along with the sensitizers can be achieved by reducing its thickness required enough to uphold the increased concentration of photoelectrons. In the photo-absorbing layer, an increase in the concentration and lessening in the mass-transfer length of photoelectrons will significantly improve the photocurrent since the consequential reduction in the rear charge transfer from $\mathrm{ZnO}$ to the electrolyte solution. The rear charge transfer is an adverse phenomenon relating to their blending of photoelectrons in a semiconducting solar cell. Therefore, to enhance the photovoltaic conversion efficiency in a DSSC, the photoabsorption coefficient of the photo-absorbing layer has to be increased. Aside from this technique, a chain of methods has been demonstrated where the generation of photo-excited charge carriers are formed by coupling nanostructured films with optical effects (light scattering or optical confinement). This method is effective in enhancing the light-producing ability of photo-electrode film, and hence enhances the DSSC performance (Usami, 1997; Zhang et al., 2012). Furthermore, researchers have envisaged that admixing the large-sized $\mathrm{TiO}_{2}$ particles will drastically improve the optical absorption and optical path length of sensitizer anchored semiconducting metal oxide nanocrystalline films (Ferber \& Luther, 1998; Lu et al., 2019; Rothenberger et al., 1999; Usami, 1999).

In recent years, researchers have proven that the efficiency of the scattering light mainly depends on the volume of scattering centres and the wavelength of incident light (Zhang et al., 2012). It was further deliberated that the light scattering attains its maximum value when the size of scattering centres is approximately or equal to ' $k \lambda$ ', where ' $k$ ' is a constant and ' $\lambda$ ' is the wavelength. Researchers have validated experimentally that the performance of DSSC can be enhanced considerably when the $\mathrm{ZnO}$ nanocrystalline films are in combination with large sized $\mathrm{SiO}_{2}$ or $\mathrm{ZnO}$ particles (Anderson \& Bard, 1997; Barbe et al., 1997; Hore et al., 2005; Li et al., 2019; So et al., 2004). Investigations are also executed by making the 
combination of photonic crystal layer with that of the conventional $\mathrm{ZnO}$ nanocrystalline films to enhance the scattering of light. This technique has resulted in enhancing the lightharvesting ability of the photo-electrode (Halaoui et al., 2005; Nishimura et al., 2003). On the other hand, combination/coupling of large-sized particles along with the nanocrystalline films has an inevitable effect by reducing the inner surface area of the photoelectrode film. This, in turn, results in neutralizing the augmentation effect of light scattering on the optical absorption, while the additional layer of photonic crystal on to $\mathrm{ZnO}$ nanocrystallite film results in an objectionable boost in the flow length of the electrons resulting in amplifying the recombination rate of photo-generated carriers. Attempts have been made to amplify the sensitizer adsorption into the $\mathrm{ZnO}$ film, by doping of nanoparticles such as $\mathrm{Au}, \mathrm{Ag}$ etc., by increasing the nano-porosity and increasing the surface area (Dhas et al., 2011; Hjiri et al., 2019; Ihara et al., 2010; Muduli et al., 2012; Ni et al., 2006). However, one significant topic is that the injection arises from the aggregation of sensitizers in a nanocrystalline films. A lot of researchers have demonstrated that solar cell performance will also be reduced due to the aggregation of the sensitizer. In an aggregated sensitizers anchored on to the surface of semiconducting metal oxide films, not all sensitizers are in direct contact with the film and hence reduces the performance of the solar cell (Kambe et al., 2000; Wenger et al., 2005).

In general, for the researchers in the field of material engineering and chemical engineering, it is still an immense challenge to come up with a material having higher efficiency, except for cautious molecular engineering of panchromatic sensitizers having enhanced lightharvesting (especially in the near-infrared region) (Nazeeruddin \& Grätzel, 2001; Nazeeruddin et al., 2001). Noteworthy, that in a DSSC adsorption of the sensitizer is a significant process which can alter/tune the solar cell performance. However, to date, the importance of the sensitizer adsorption and its effect on solar cell performance has not been thoroughly understood. It is well-accepted that in a DSSC, high-efficiency photo-electrode requires a high surface area for the loading of sufficient amounts of sensitizer molecules. Along with it the rapid electron transmission and deliberate electron recombination are the key factors in achieving higher efficiency (Nakade et al., 2003; Wang et al., 2020; Wang et al., 2006). Hence, more investigation has to recompense on the sensitizer's adsorption onto the $\mathrm{ZnO}$ film, surface area, ability of light scattering and fast electron transport. In this article, we report on the novel $\mathrm{Ni}(\mathrm{II})\left(\mathrm{Q}_{1}\right)_{2}$ complex-adsorption onto $\mathrm{ZnO}$ film fabricated by the combination of small $(\sim 25 \mathrm{~nm})$ and large $(\sim 200 \mathrm{~nm}) \mathrm{ZnO}$ nanoparticles. In the present article, instead of other metal-oxides, $\mathrm{ZnO}$ nanoparticles were used since $\mathrm{ZnO}$ is non-toxic and inexpensive.

\section{Materials and Methods}

\subsection{Materials}

Isatin $\left(\mathrm{C}_{8} \mathrm{H}_{5} \mathrm{NO}_{2}\right)$, Potassium hydroxide $(\mathrm{KOH})$, dimethylglyoxime $\left(\mathrm{C}_{4} \mathrm{H}_{8} \mathrm{~N}_{2} \mathrm{O}_{2}\right)$, Hydrochloric acid $(\mathrm{HCl})$, petroleum ether, ethanol, $\mathrm{ZnO}$ nanoparticles, terpineol, ethylcellulose and Indium-doped tin oxide (ITO) were supplied from Sigma-Aldrich. Distilled water was used throughout the experiment.

\subsection{Instrumentation and Characterization}

The working electrode was made-up using two different varieties of $\mathrm{ZnO}$ based on the size of the particle. Approximately $25 \mathrm{~nm}$ and $200 \mathrm{~nm}$-sized $\mathrm{ZnO}$ nanoparticles were purchased from Sigma Aldrich. These two types of $\mathrm{ZnO}$ nanoparticles were used in the preparation of the film in four different ratios. The as-prepared film was further subjected to characterization. The surface morphologies of the samples were investigated using SEM (JSM-6710F, JEOL; Japan). The optical property of the film before and after deposition of sensitizer and the role of $\mathrm{Ni}(\mathrm{II})-\left(\mathrm{Q}_{1}\right)_{2}$ complex in the absorptions of light was studied using UV-vis spectroscopy 
(model UV-2550). The adsorption of $\mathrm{Ni}(\mathrm{II})-\left(\mathrm{Q}_{1}\right)_{2}$ complex on $\mathrm{ZnO}$ films were measured by ATR-IR spectrophotometer. The optical thickness of the instrument was measured by optical fibre instrument. Liquid chromatography coupled with mass spectrometry (LC-MS - model SHIMADZU 2010A) was used to observe the base peak. FT-IR (BRUKER desktop) was used to determine the functional group of the $\mathrm{Ni}(\mathrm{II})-\left(\mathrm{Q}_{1}\right)_{2}$ complex. The specific surface area of the samples was determined using Autosorb-1C (Quantachrome, USA) unit. ${ }^{1} \mathrm{HNMR}$ was used to characterize the $\mathrm{Ni}(\mathrm{II})-\left(\mathrm{Q}_{1}\right)_{2}$ complex. The photocurrent-voltage characteristics of the DSSCs were measured under simulated solar illumination with a light intensity of $100 \mathrm{~mW} \mathrm{x}$ $\mathrm{cm}^{-2}$ (AM 1.5 G) using a sol 3A Class AAA Solar Simulator.

\subsection{Synthesis of 2-[(1Z)-N-hydroxyethanimidoyl] quinoline-4-carboxylic acid ( $\left.Q_{1}\right)$}

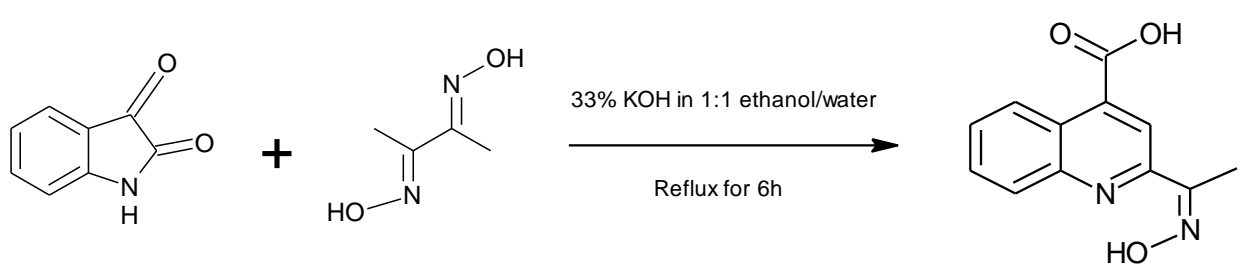

Figure 1. Synthesis of 2-[(1Z)- $N$-hydroxyethanimidoyl] quinoline-4-carboxylic acid

In the synthesis of 2-[(1Z)- $N$-hydroxyethanimidoyl] quinoline-4-carboxylic acid ( $\left.\mathrm{Q}_{1}\right)$ (Figure 1), $1 \mathrm{mmol}$ of Isatin was added in $33 \%$ of $\mathrm{KOH}$ solution. To this reaction mixture $1.1 \mathrm{mmol}$ of dimethylglyoxime was added with continued stirring and refluxed for 6 hours. The completion of the reaction was determined by thin layer chromatography (TLC) technique. When the reaction is completed, the reaction mixture was cooled to room temperature. The obtained compound was acidified by adding $1 \mathrm{~N} \mathrm{HCl}$ dropwise until the $\mathrm{pH}$ of the solution reaches to 3. Precipitation of pale red coloured powder was noticed, which was further separated by filtration and washed with de-ionized water 2-3 times followed by pet-ether. The residual product obtained was further purified by silica gel chromatography (eluentchloroform: methanol, 9:1 v/v)(Nicolini, 1996 ).

2.4. Synthesis of [(2-[(1Z)-N-hydroxyethanimidoyl] quinoline-4-carboxylic acid $)_{2} \mathrm{Ni(II)]}$ complex $\left(\mathrm{Ni}(\mathrm{II})-\left(\mathrm{Q}_{1}\right)_{2}\right.$ complex $)$

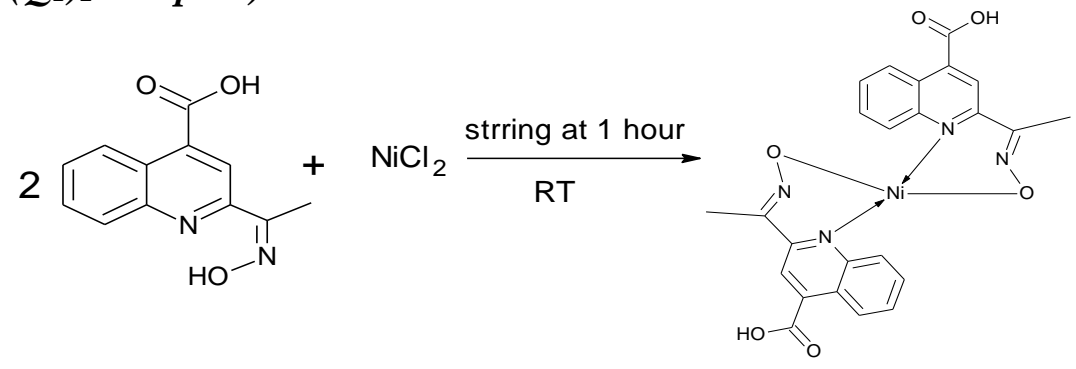

Figure 2. [(2-[(1Z)- $N$-hydroxyethanimidoyl] quinoline-4-carboxylic acid $)_{2} \mathrm{Ni}$ (II)] complex

In the synthesis of [(2-[(1Z)- $N$-hydroxyethanimidoyl] quinoline-4-carboxylic acid) $2 \mathrm{Ni}$ (II)] complex (Figure 2), synthesized ligand $\left(\mathrm{Q}_{1}\right)$ of $0.5 \mathrm{mmol}$ was used as the starting material. $\mathrm{Q}_{1}$ was dissolved in $10 \mathrm{ml}$ of ethanol. To this mixture, an equivalent quantity of metal salt solution in $20 \mathrm{ml}$ ethanol (95\%) was added dropwise with continued stirring. The solution was added until the brick-red precipitate was formed. Finally, the obtained precipitate was filtered, washed with de-ionized water followed by pet-ether and dried.

\subsection{Preparation of $\mathrm{ZnO}$ films}

Commercially available $\mathrm{ZnO}$ nanoparticles were used for the preparation of $\mathrm{ZnO}$ films. The films prepared were of different ratios between small and large particles. The ratios of $\mathrm{ZnO}$ 
small: large particles are: 100:0, 90:10, 60:40 and 50:50. The samples were named as ZL0, ZL10, ZL40, and ZL50 where the numbers quantify the amount of larger ZnO particles in term of $\%$ present in the film. The processing of $\mathrm{ZnO}$ film of various ratios has a significant impact on the material properties. The properties include surface structure, porosity, optical light scattering, electron transport properties, and film roughness. All of these factors play a prominent role in determining the performance of photoanode (Kashyout et al., 2010; Lee et al., 2010; Liao et al., 2012; Suttiponparnit et al., 2011; Wang et al., 2004). Generally, the commercially available $\mathrm{ZnO}$ nanoparticles are aggregated, and hence these particles exhibit less performance when compared to the synthesized particles (Ocakoglu et al., 2008). To avoid aggregation of the $\mathrm{ZnO}$ particles, these $\mathrm{ZnO}$ particles were ground using the engineering built top planetary ball mill. The rotation speed of the agitator was set at $500 \mathrm{rpm}$ and rotation time was set as 40 min under wet condition. Noteworthy, the planetary ball milling method will successfully reduce the particles aggregation leading to better dispersion stability. It should also be noted that to fabricate the effective DSSC the dispersion stability of $\mathrm{ZnO}$ nanoparticles should be in base fluid (Habibzadeh et al., 2010). Further, to have better dispersion, the $\mathrm{ZnO}$ particles of four different compositions were dispersed in ethanol solution and ultrasonicated for $40 \mathrm{~min}$. This helps break the attractive van der Waals force among the $\mathrm{ZnO}$ particles at contact.

The $\mathrm{ZnO}$ paste was prepared using the $\mathrm{ZnO}$ nanoparticles (of various ratios of small: large particles) obtained after ultrasonication. Terpineol and ethyl cellulose were added to these $\mathrm{ZnO}$ nanoparticles and stirred using a magnetic stirrer for $48 \mathrm{~h}$. Indium-doped tin oxide (ITO) glass substrates (Sigma Aldrich) having a sheet resistance of $8 \Omega / \mathrm{sq}$ was ultrasonicated, cleaned using acetone, ethanol and distilled water for 15 minutes to ensure the complete removal of organic pollutants and other contamination. Doctor blade technique was employed for coating the complex paste of different $\mathrm{ZnO}$ nanoparticles onto the cleaned ITO glass substrate. Literature review states that the, highest efficiency was obtained when the thickness of $\mathrm{ZnO}$ film was restricted up to 14 to $15 \mu \mathrm{m}$ (Keis et al., 2002). In the present work, the $\mathrm{ZnO}$ film with approximately $5 \mu \mathrm{m}$ thickness and $1 \times 1 \mathrm{~cm}^{2}$ of surface area was fabricated. The obtained $\mathrm{ZnO}$ films were calcined at $450{ }^{\circ} \mathrm{C}$ for $1 \mathrm{~h}$. After calcination, $\mathrm{ZnO}$ films were dipped in $0.3 \mathrm{mM}$ solution of $\mathrm{Ni}(\mathrm{II})\left(\mathrm{Q}_{1}\right)_{2}$ complex in presence of anhydrous ethanol for $24 \mathrm{~h}$. After $24 \mathrm{~h}$, the sensitizing molecules were completely absorbed by the film. $\mathrm{ZnO}$ electrodes impregnated with sensitizer of the various amount was assembled along with the earlier developed platinum counter electrodes. The electrolyte, KI, and $\mathrm{I}_{2}$ (iodide-based redox electrolyte) were added into the cell via back filling through the injection hole on the counter electrode side.

Table1.

The experimental condition of DSSCs fabricated

\begin{tabular}{|c|c|c|c|c|c|}
\hline \multicolumn{6}{|c|}{ Incorporation of $\mathrm{ZnO}$ nanoparticles in $\mathrm{wt} \%$} \\
\hline Samples & $15 \mathrm{~nm} \mathrm{ZnO}$ & $200 \mathrm{~nm} \mathrm{ZnO}$ & $\begin{array}{c}\text { The thickness } \\
\text { of the film }\end{array}$ & $\begin{array}{l}\text { Coating } \\
\text { method }\end{array}$ & $\begin{array}{c}\text { Counter } \\
\text { electrode }\end{array}$ \\
\hline ZLO & 100 & 0 & $5 \mu \mathrm{m}$ & Doctor blade & Pt electrode \\
\hline ZL10 & 90 & 10 & $5 \mu \mathrm{m}$ & Doctor blade & Pt electrode \\
\hline ZL40 & 60 & 40 & $5 \mu \mathrm{m}$ & Doctor blade & Pt electrode \\
\hline ZL50 & 50 & 50 & $5 \mu \mathrm{m}$ & Doctor blade & Pt electrode \\
\hline
\end{tabular}

\section{Results and Discussion}

\section{1. ${ }^{1} \mathrm{H}$ NMR studies of $\mathrm{Ni}(\mathrm{II})-(\mathrm{Q1}) 2$ complexes}

${ }^{1} \mathrm{H}$ NMR is an advanced technique where more than hundreds /thousands of resonance lines is obtained in the spectrum of a macromolecule which can be witnessed as individual peaks. It also provides the selectivity and the correlations between pairs of spins /groups of equivalent spins. It is also helpful in identifying the number of $1 \mathrm{H}-1 \mathrm{H}$ nuclear Overhauser 
effects (NOEs). The ${ }^{1} \mathrm{H}$ NMR analysis of the $\mathrm{Ni}(\mathrm{II})-\left(\mathrm{Q}_{1}\right)_{2}$ complexes sample was performed. Figure 3 corresponds to the ${ }^{1} \mathrm{H}$ NMR spectrum of $\mathrm{Ni}(\mathrm{II})-\left(\mathrm{Q}_{1}\right)_{2}$ complexes acid sample. The as-prepared compound was purified by silica gel chromatography (eluent-chloroform: methanol, 9:1 v/v). In the ${ }^{1} \mathrm{H}$ NMR spectra the function that corresponds to the particular $\delta$ ppm scale and their readings are given as follows: ${ }^{1} \mathrm{H}$ NMR (DMSO- $\mathrm{d}_{6}, 400 \mathrm{MHz}$ ): The $\delta$ ppm scale at 13.9 corresponds to $(\mathrm{s}, 1 \mathrm{H}, \mathrm{COOH})$. Similarly, at $8.0 \mathrm{ppm}$ is $(\mathrm{d}, 1 \mathrm{H}$ pyridine $3 \mathrm{C}-\mathrm{H})$, benzene at $7.6 \mathrm{ppm}(\mathrm{d}, 1 \mathrm{H}, \mathrm{Ar}-\mathrm{H}), 7.5 \mathrm{ppm}(\mathrm{d}, 1 \mathrm{H}, \mathrm{Ar}-\mathrm{H}), 7.1 \mathrm{ppm}(\mathrm{t}, 1 \mathrm{H}, \mathrm{Ar}-\mathrm{H})$ $6.9 \mathrm{ppm}(\mathrm{d}, 1 \mathrm{H}, \mathrm{Ar}-\mathrm{H}), 11.4 \mathrm{ppm}(\mathrm{s}, 1 \mathrm{H},-\mathrm{N}-\mathrm{OH})$ and the aliphatic protons at $1.9 \mathrm{ppm}(3 \mathrm{H}$, s). From the Figure.3, it is clear that the ${ }^{1} \mathrm{H}$ NMR spectrum of the material exhibited multiplet in the region 6.8-7.6 ppm. This region is assigned to the aromatic protons of the benzene ring present in the sample. A singlet at $7.9 \mathrm{ppm}$ was observed, due to one proton which corresponds to the pyridine ring. Similarly, a singlet was observed at $1.9 \mathrm{ppm}$, which is considered as the three aliphatic protons of $-\mathrm{CH}_{3}$ group. The peak in the region at $14 \mathrm{ppm}$ represents the significant signal of a carboxylic proton (broad) (Issa et al., 2009; Kimtys \& Balevicius, 1979; Nicolini, 1996 ).

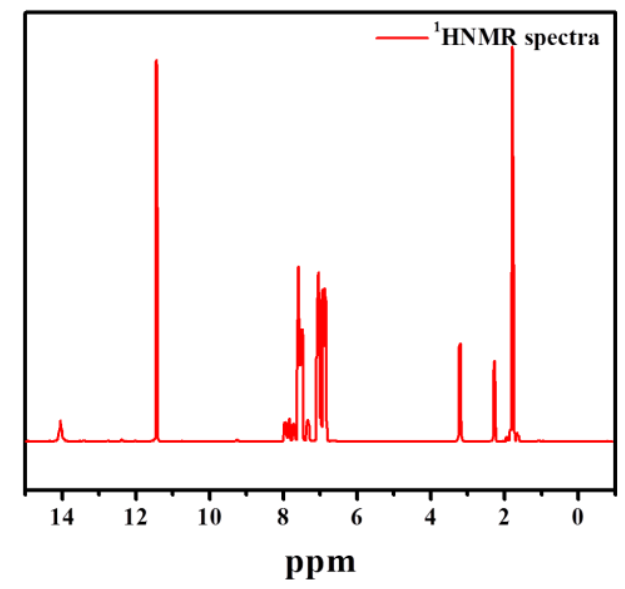

Figure 3. ${ }^{1} \mathrm{H}$ NMR spectrum of 2-[(1Z)- $N$-hydroxyethanimidoyl] quinoline-4- carboxylic acid.

\subsection{The liquid chromatography-mass spectrum (LC-MS) studies of $\mathrm{Ni}(\mathrm{II})-\left(Q_{1}\right)_{2}$ complexes}
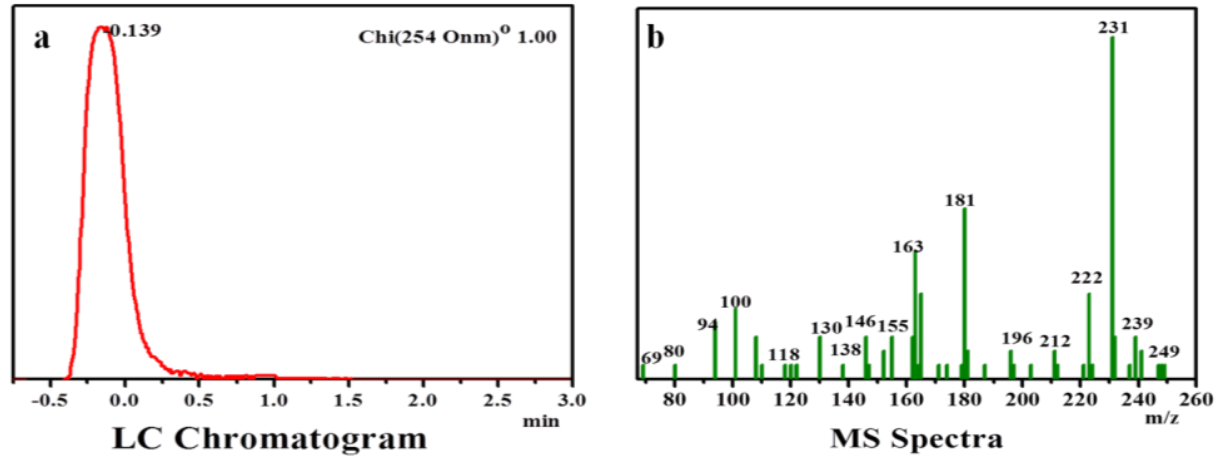

Figure 4. LC-MS studies of 2-[(1Z)- $N$-hydroxyethanimidoyl] quinoline-4-carboxylic acid

The mass spectrum was analyzed in LC-MS. The chromatogram obtained for the as-prepared sample is given in Figure 4a. The molecular ion peak of the fabricated compound shows $[\mathrm{M}+1]$. The mass spectra obtained for the as-prepared sensitizer is given in Figure $4 \mathrm{~b}$. In Figure $4 \mathrm{~b}$, the molecular ions represent the base peaks in the spectra and hence, under electron impact, reflect their stable nature. The base peak of the obtained compound was $\mathrm{m} / \mathrm{z}$ $=231(\mathrm{M}+\mathrm{H})$. 


\subsection{FT-IR spectral studies of $\mathrm{Ni}(\mathrm{II})-\left(Q_{1}\right)_{2}$ complexes}

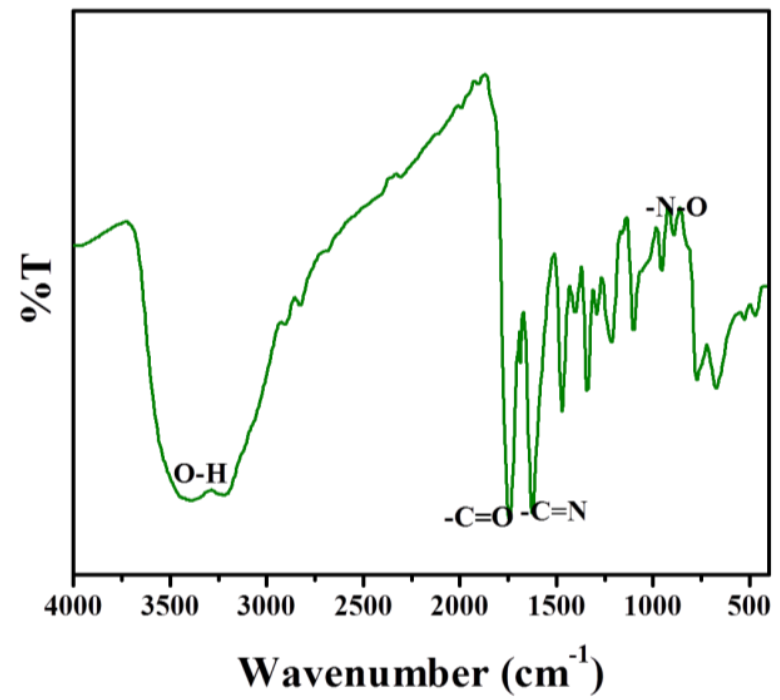

Figure 5. FT-IR spectra of Ni(II)-( $\left(\mathrm{Q}_{1}\right)_{2}$ complexes

The FT-IR spectrum of $\mathrm{Ni}(\mathrm{II})-\left(\mathrm{Q}_{1}\right)_{2}$ complexes recorded is given in Figure 5. The stretching bands in the region at $3381 \mathrm{~cm}^{-1}, 1735 \mathrm{~cm}^{-1}, 1616 \mathrm{~cm}^{-1}$, and $945 \mathrm{~cm}^{-1}$ are assigned to (-OH), ($\mathrm{C}=\mathrm{O}),(-\mathrm{C}=\mathrm{N})$ and $(-\mathrm{N}-\mathrm{O})$ stretching vibrations. After the development of $\mathrm{Ni}(\mathrm{II})-\left(\mathrm{Q}_{1}\right)_{2}$ complex, these stretching bands were shifted around $5 \mathrm{~cm}^{-1}$ due to the coordination of $\mathrm{OH}$ group of the oxime and nitrogen to the metal ion. The band at the region $945 \mathrm{~cm}^{-1}$ is attributed to the oxime $\mathrm{N}-\mathrm{O}$ stretching of ligand, once the formation of the metal complex this band of $\mathrm{N}-\mathrm{O}$ stretching has been shifted towards lower region confirming the co-ordination of the $-\mathrm{OH}$ group of the oxime to the metal ion. The intense band at $1735 \mathrm{~cm}^{-1}$ is ascribed to $\mathrm{C}=\mathrm{O}$ which indicates the occurrence of $\mathrm{C}=\mathrm{O}$ group still after the development of the metal complex.

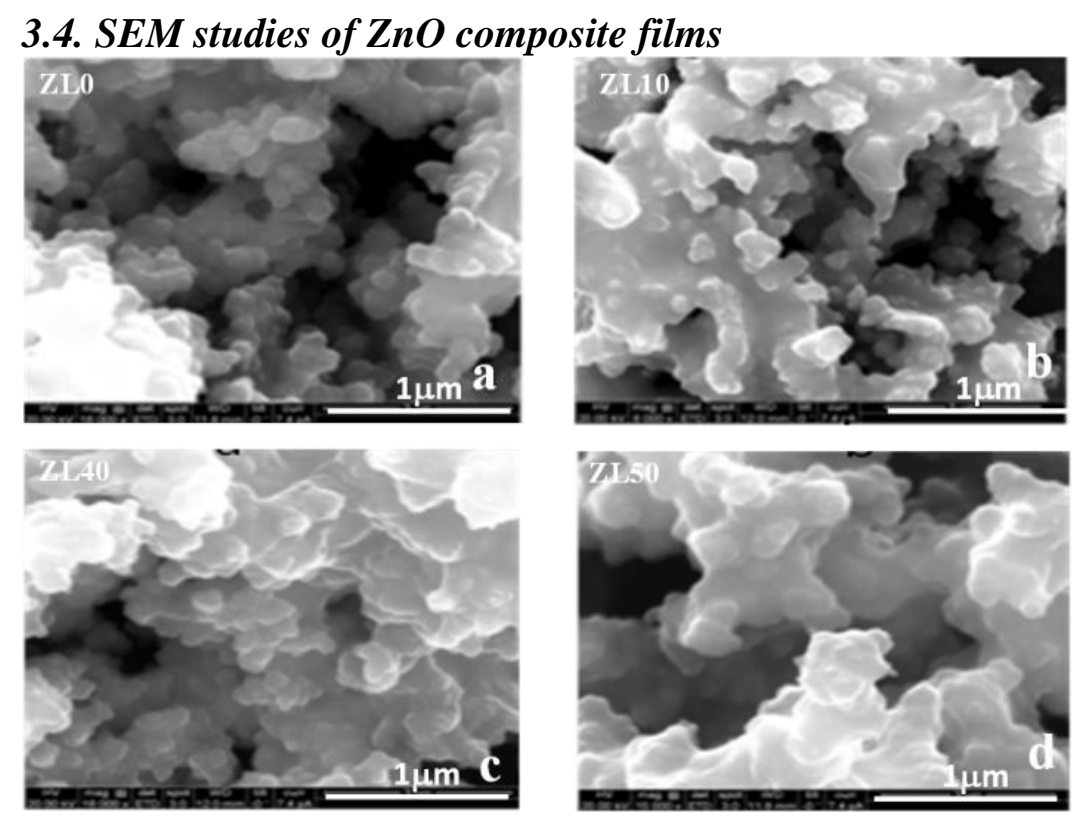

Figure 6. The surface sectional scanning electron microscope (SEM) images of the $\mathrm{ZnO}$ films prepared as the compositions of small and large $\mathrm{ZnO}$ nanoparticles

The surface sectional SEM studies were performed to know the arrangement of the small and large $\mathrm{ZnO}$ nanoparticles on to the film. Figure $6 \mathrm{a}$, shows the regularly arranged small $(\sim 25$ $\mathrm{nm}) \mathrm{ZnO}$ particle with the high surface area. Several hundreds of uniform nanoparticles were 
observed. Some literature states that the in DSSC the improvement of photovoltaic performance is governed by using small $\mathrm{ZnO}$ particle having high surface area and high mesoporous(Lee et al., 2012). However, it is believed that the contact area between the $\mathrm{ZnO}$ nanoparticles and ITO glass substrate, which is very high, helps in improving the efficiency of the cell (Yu et al., 2011). It is to be noted that the absorption of light by small $\mathrm{ZnO}$ particle is very less, and hence results in the decreased in photovoltaic efficiency. The reason behind this is the deficiency in the scattering effect caused by the small nanoparticles. Noteworthy, that the reflectance intensity mainly depends on both the scattering ability of the individual particles and the travelling path of the scattered light within the film (Nelson \& Deng, 2008).

Researchers have suggested that the aforementioned issues in the DSSC and improving them can be done by introducing larger particles (Yu et al., 2011). In general, particles having higher specific surface area and larger porous film electrode favours the improvement of photoelectric conversion efficiency, since they possess more surface active sites. The presence of surface-active sites increases the adsorption of sensitizers and also in the ease moment of electrolyte through the interconnected porous networks. It also improvises the harvesting of light (Lee et al., 2012). Most of the reported literature reveals that the larger $\mathrm{ZnO}$ particles possess higher light-scattering ability than that of small nanoparticles. This intense scattering ability of large particles can be ascribed to at least two reasons. Firstly, the unique hollow structure of large particles is beneficial for light scattering. The increase in the light scattering within the hollow cavity increases the path length of the incident light, meanwhile the multi-reflection influences for the enhancement of scattering intensity (Kondo et al., 2008; Yu \& Chen, 2008). Secondly the large particle semiconducting oxide films have possessed a void volume, which is beneficial to the improvement of light scattering (Nelson \& Deng, 2008; Yu et al., 2011). These better physical properties of a large particle would show higher adsorption of sensitizer molecules and higher light scattering effect resulting in the enhancement of photovoltaic performance.

Based on the above findings, the larger particles were introduced along with the small $\mathrm{ZnO}$ particles. In Figure 6b, one can witness the fewer number of $\mathrm{ZnO}$ large particles mixed with $\mathrm{ZnO}$ small nanoparticles with the view of improving the light scattering ability and sensitizer adsorption. The pore size of the samples ZL10, ZL 40 and ZL 50 in Figure 6, have slightly changed to larger size depending on the added amount of larger particle, which would further improve the sensitizer's adsorption into the film.

\subsection{UV-Visible absorbance spectral studies of $\mathrm{ZnO}$ composite films and sensitizer deposited $\mathrm{ZnO}$ composite}
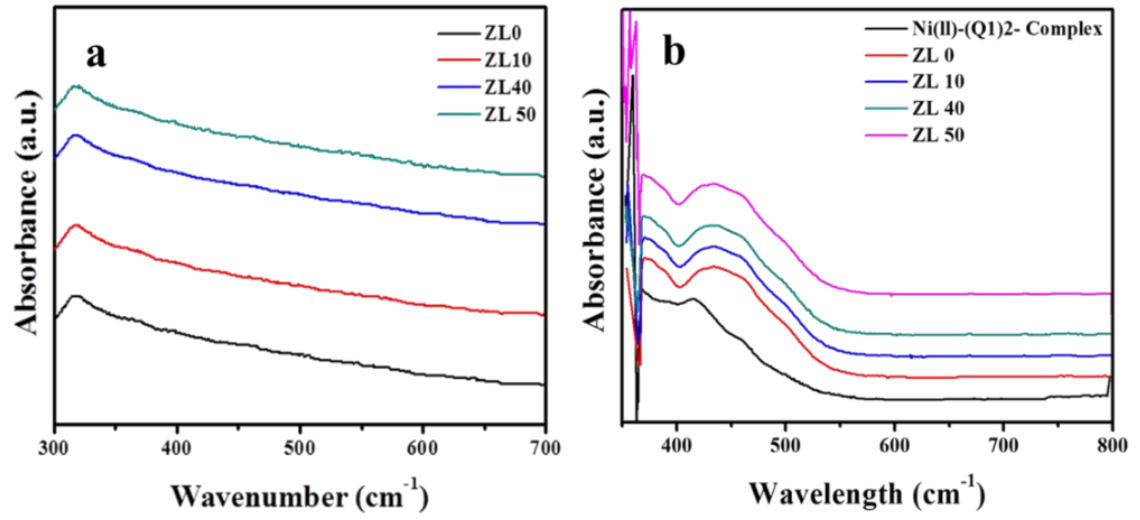

Figure 7. The UV-visible absorbance spectrum of $\mathrm{ZnO}$ and c $\mathrm{Ni}(\mathrm{II})-\left(\mathrm{Q}_{1}\right)_{2}$ complexes formed films

The UV- vis spectral studies for the prepared samples were performed to know the ability of the film when exposed to light concerning the ratio of large and small $\mathrm{ZnO}$ particles. Figure7, 
corresponds to the UV light absorbance spectra of four different $\mathrm{ZnO}$ samples in the wavelength ranging from 300 to $800 \mathrm{~nm}$. Figure 7, clearly confirms that there is no blue or redshift in the spectral absorbance on the incorporation of $\mathrm{ZnO}$ larger size particle with the small particle. However, it was observed that the UV light absorbance has increased gradually with increase in loading of $\mathrm{ZnO}$ particles of larger size. Further, the combination of small and large $\mathrm{ZnO}$ particles in the ratio 1:1 shows much absorption compared to other samples. The increase in the absorbance is due to the formation of hollow cavities between the particles, which might favour absorption and scattering of light. Meanwhile, the lowest light absorbance was achieved by the sample fabricated by using only the small $\mathrm{ZnO}$ particles. The lessening of light absorption might lead to poor photovoltaic efficiency. The increment of the light absorbance phenomena can be explained as a hollow cavity between large particles. The possible factors affecting the change in absorbance of four $\mathrm{ZnO}$ films with sensitizer sensitization were recorded. From Figure $7 \mathrm{~b}$, it is obvious that all $\mathrm{ZnO}$ films show a native absorption with comparable absorption intensity below $390 \mathrm{~nm}$, which is caused by the $\mathrm{ZnO}$ semiconductor owing to the electron transfer from the valence band to the conduction band. However, the absorbance of the samples at wavelengths above $400 \mathrm{~nm}$ varies considerably; these absorbances are originated from the sensitizer molecules which are adsorbed on to the surface of $\mathrm{ZnO}$ and are linked to the film structure. Figure $7 \mathrm{~b}$ also depicts that all the samples adorned by sensitizer consist of an absorption peak which is centred on $430 \mathrm{~nm}$. This adsorption peak corresponds to the electronic coupling/ the heterojunction formed between the sensitizer and $\mathrm{ZnO}$ nanocrystalline films which will be evidence for a broad absorbance band and the shift towards the visible region. Furthermore, the absorption spectra specify that the sample ZL 50 bring on more effectual photon capturing in the visible region confirming the prolongation of strong light-scattering effect. This effect could somewhat scatter the incident light and deteriorates the transmittance of the films resulting in the simulated absorption deviating from the adsorbed sensitizer.

\subsection{BET specific surface area studies of ZnO composite films}

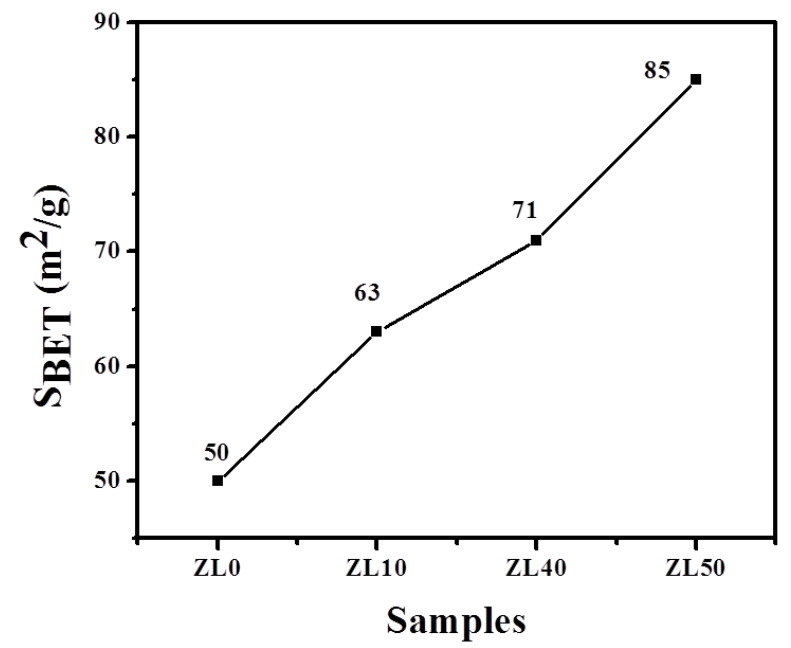

Figure 8. BET specific surface area of $\mathrm{ZnO}$ coated films

BET surface area studies for the representative samples were measured to know the specific surface area of the $\mathrm{ZnO}$ deposited on to the film. Figure 4 depicts the BET surface area of relatively different size mixture of $\mathrm{ZnO}$ particles. The BET specific surface areas were 50, 63, 71, and $85 \mathrm{~m}^{2} \mathrm{~g}^{-1}$ for the samples ZL0, ZL10, ZL 40 and ZL 50 respectively. It is evident from Figure 4 that the BET surface area of samples slightly increased with the increasing the quantity/number of larger $\mathrm{ZnO}$ particles. The results obtained are in agreement with the UV 
data suggesting that the presence of these pores will be beneficial in the harvesting of light which in turn will enhance the efficiency of the material.

\subsection{ATR-IR spectral bands of $\mathrm{Ni}(\mathrm{II})-\left(Q_{1}\right)_{2}$ sensitizer adsorbed on $\mathrm{ZnO}$ films and free $\mathrm{Ni}(\mathrm{II})-\left(Q_{1}\right)_{2}$ complex}

The characteristics of the molecular species adsorbed on the substrate can be determined by the infrared spectra. Even the smaller shifts in the band position material can be observed. Upon this, deprotonation/ surface coordination/any change in the symmetry of complexes leads to variation in the number and position of bands which can also be determined by IR studies.

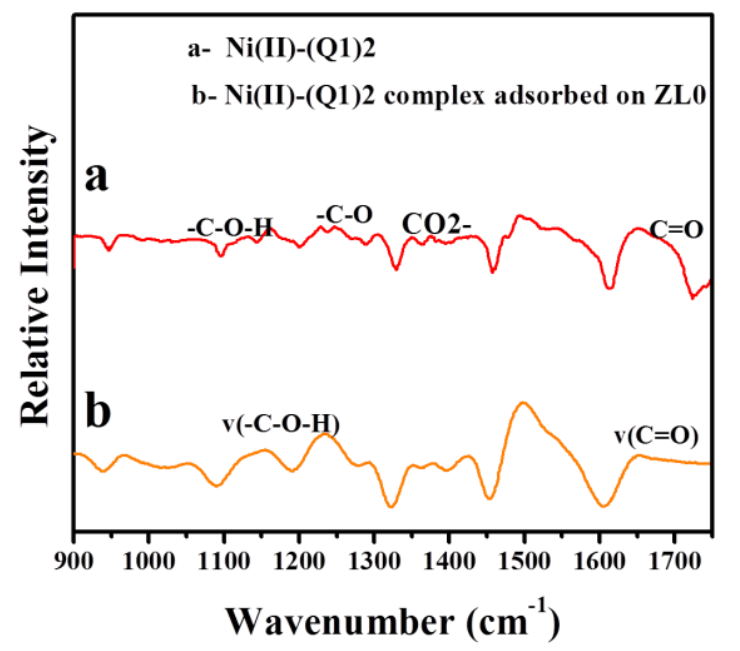

Figure 9. The ATR-IR spectrum of (a) Ni(II)-( $\left(\mathrm{Q}_{1}\right)_{2}$ complex and (b) $\mathrm{Ni}(\mathrm{II})-\left(\mathrm{Q}_{1}\right)_{2}$ complex adsorbed on ZL0 sample

Figure 9, shows that ATR-IR spectral bands of $\mathrm{Ni}(\mathrm{II})-\left(\mathrm{Q}_{1}\right)_{2}$ complex and $\mathrm{Ni}(\mathrm{II})-\left(\mathrm{Q}_{1}\right)_{2}$ sensitizer adsorbed on $\mathrm{ZnO}$ films. The major IR spectral bands obtained for the $\mathrm{Ni}(\mathrm{II})-\left(\mathrm{Q}_{1}\right)_{2}$ sensitizer lies at $1728 \mathrm{~cm}^{-1}$ for the $\mathrm{C}=\mathrm{O}$ stretching. The region at $1618 \mathrm{~cm}^{-1}$ is the asymmetric stretching of $\mathrm{CO}_{2}$. The band lying in the region $1332 \mathrm{~cm}^{-1}$ is assigned to symmetric stretching of $\mathrm{CO}_{2}^{-}$. The band $1147 \mathrm{~cm}^{-1}$ corresponds to the $(-\mathrm{C}-\mathrm{O}-\mathrm{H})$ bending and $1201 \mathrm{~cm}^{-1}$ corresponds to single bond (-C-O) stretching. In the present work both $-\mathrm{C}=\mathrm{O}$ and $-\mathrm{CO}_{2}^{-}$ stretching bands were observed confirming that both protonated and deprotonated carboxylic groups are there in the $\mathrm{Ni}(\mathrm{II})-\left(\mathrm{Q}_{1}\right)_{2}$ sample. The IR spectra of $\mathrm{Ni}(\mathrm{II})-\left(\mathrm{Q}_{1}\right)_{2}$ complex adsorbed on $\mathrm{ZnO}$ films showed a complete reduction in the relative intensity when $\mathrm{ZnO}$ adsorbed, which is due to $(v(\mathrm{C}=\mathrm{O}))$. This further leads to a conclusion that the $\mathrm{Ni}(\mathrm{II})-\left(\mathrm{Q}_{1}\right)_{2}$ complex was put together through bidentate coordination(BC), instead of monodentate coordination (MC) [48]. The band at $1143 \mathrm{~cm}^{-1}$ which is assigned to $(v(-\mathrm{C}-\mathrm{O}-\mathrm{H}))$ was also absent upon adsorbing on $\mathrm{ZnO}$, which further validate the bidentate surface complex formation at the surface.

\subsection{Photovoltaic Studies}

The as-prepared films were subjected to photovoltaic studies by measuring current-voltage performance irradiated by modified AM 1.5 sunlight with a power density of $100 \mathrm{~mW} / \mathrm{cm}^{2}$ which is given in Figure 10. The overall detail of the photovoltaic studies such as current density versus voltage curves, The short circuit photocurrents (Jsc), open-circuit photovoltages (Voc); fill factors (FF), and the energy conversion efficiencies $(\eta)$ for the four samples are summarized in Table 2. From the results, Jsc values of sample ZL0, ZL10, ZL40, and ZL 50 were deliberated as $0.92 \mathrm{~mA} * \mathrm{~cm}^{-2}, 1.0 \mathrm{~mA} * \mathrm{~cm}^{-2}, 1.18 \mathrm{~mA} * \mathrm{~cm}^{-2}$, and 1.23 $\mathrm{mA} * \mathrm{~cm}^{-2}$. We noticed that by increasing the part of larger particles the Jsc values were 
increased. The enhancement is based on the adsorbed amount of sensitizer molecules and having strong light scattering ability into the films from the higher hollow cavity having a larger pore size (Yu et al., 2011). The Voc and FF values of sample's ZL0, ZL10, ZL40, and $\mathrm{ZL} 50$ were measured as $0.47 \mathrm{~V}, 0.446 \mathrm{~V}, 0.42 \mathrm{~V}, 0.38 \mathrm{~V}$ and $29,28.3,26.5,25.9$, respectively. According to our observation, both the Voc and FF values decreased with increasing the concentration of large particles. The decrease in these values is due to a decrease in the specific surface area resulting in the poor contact area between the $\mathrm{ZnO}$ particles and ITO glass substrate.

Most of the literature states that the enhanced electrochemical activity can be achieved by increasing the surface area of nanoparticles. In ZL0 sample, a similar signal of the photocurrent-voltage was observed. This might be due to (i) high surface area, (ii) good contact area and (iii) high mesoporous structure. The increase surface area and the good contact area of the electrode may encourage the reaction of $\mathrm{I}^{-3}$ reduction at the boundary between the particle and the electrolyte which improvises the FF. Furthermore, higher electrochemical activity produces higher Voc values. The greater mesoporous structures of $\mathrm{ZnO}$ electrode was produced due to the involvement of small nanoparticles by increasing the electron charge transfer. Meanwhile, as the mesoporous structures increases in a $\mathrm{ZnO}$ electrode, the electron charge transfer increases which enhance the electrochemical activity of the $\mathrm{ZnO}$, resulting in higher Voc values and lower Jsc values $\left(0.92 \mathrm{~mA} * \mathrm{~cm}^{-2}\right)$ for ZL0 sample when compared with other samples. This results in less efficiency $(0.12 \%)$, which is comparatively less than that of the other solar cells. The lesser Jsc value is a cause of fewer depositions of sensitizer molecules and deprived light scattering ability. However, in sample ZL10 the Jsc values increases to $1.0 \mathrm{~mA} * \mathrm{~cm}^{-2}$ which might be due to faintly increase in the sensitizer molecule adsorption when compared to the sample ZL0 sample with an insignificant decrease in the Voc and FF values from $0.47 \mathrm{~V}$ to 0.446 since the decrease in surface area and mesoporous structure. Consequently, on the whole, the photovoltaic efficiency is $0.126 \%$, which is higher than that of sample ZL0. Further, the sample ZL40 exhibits a higher photovoltaic efficiency of $0.132 \%$, which is also comparatively higher than that of the ZL0 sample. Even the Voc and FF values of ZL40 slightly decreased to $0.42 \mathrm{~V}$ and 26.5. Similarly, the Voc and FF values further decrease, and the Jsc value $\left(1.18 \mathrm{~mA} * \mathrm{~cm}^{-2}\right)$ was strongly increased compared to both sample ZLO and ZL10 caused by the excessive sensitizer adsorption and strong light scattering ability into the film. However, when the sample ZL50 was used there was a decrease in the performance of the photovoltaic cell (0.123) when compared to ZL40. Hence, our result leads to the conclusion that the proportion used for the ZL40 sample is as an optimal incorporation ratio of small and large $\mathrm{ZnO}$ particles to improve the photovoltaic performance of DSSC.

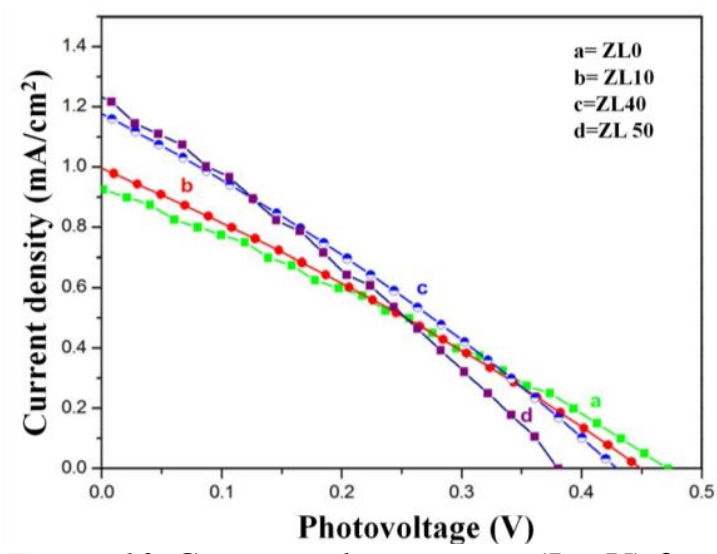

Figure 10. Current-voltage curves (Jsc-V) for the ZL0, ZL10, ZL40 and ZL50 samples. 
Interestingly, the Jsc value of $\left(1.23 \mathrm{~mA} * \mathrm{~cm}^{-2}\right)$ sample ZL50 was still increased due to more sensitizer adsorption and stronger light scattering ability than that of ZL40. According to Table 3, even though the there is an increase in the Jsc value, the Voc $(0.38 \mathrm{~V})$ and FF (25.9) values have decreased, which in turn decreases the photovoltaic efficiency. The decrease in the photovoltaic efficiency based on the values of Voc and FF could be explained concerning the large surface area and poor contact area. The unusual development of the large surface area having the poor contact area between the $\mathrm{ZnO}$ particles and ITO glass substrate is the main reason for the decrease in the photovoltaic efficiency. There are some more possible reasons for the decrease in the photovoltaic effect which might be connected with the aggregation of sensitizers onto the surface of the film (Katoh et al., 2002). Notably, the solar cell performance depends on the load of the sensitizer, the higher the sensitizer load, the lesser the performance (Kambe et al., 2000; Wenger et al., 2005). The above studies lead to the conclusion that the incorporation of $\mathrm{ZnO}$ particles of various, by optimizing the proportion within one film electrode will possibly lead to better photovoltaic conversion efficiency.

Table 2.

Values Showing the Open-Circuit Voltage, Short-Circuit Current Density, and Overall Light Conversion Efficiency for different sized, different composition of $\mathrm{ZnO}$ Film Electrodes Sensitized by $\mathrm{Ni}(\mathrm{II})-\left(Q_{1}\right)_{2}$ complex.

\begin{tabular}{ccccc}
\hline Samples & $\operatorname{Voc}(\mathrm{V})$ & $\mathrm{Jsc}\left(\mathrm{mA} \mathrm{cm}^{-2}\right)$ & $\mathrm{FF}$ & $\eta(\%)$ \\
\hline Sample a & 0.47 & 0.92 & 29 & 0.12 \\
Sample b & 0.446 & 1.0 & 28.3 & 0.126 \\
Sample c & 0.42 & 1.18 & 26.5 & 0.132 \\
Sample d & 0.38 & 1.23 & 26.1 & 0.123 \\
\hline
\end{tabular}

Based on our overall study, we can conclude that the light scattering ability ZLO sample is less compared to that of ZL10 sample which is caused due to the larger pore size. However, the enhancement in the photovoltaic efficiency is not too high using ZL10 sample. When $10 \%$ of the larger particles were incorporated, a few hollow cavities were formed which was later filled by smaller $\mathrm{ZnO}$ particles, which leads to the lower light scattering ability, which is in agreement with the Figure 6b. This retards the optical beam of light passing through the ITO glass substrate and contact with the $\mathrm{ZnO}$ film.

The case of ZL40 samples, the ZnO film has more voids and pore size when compared to that of ZL10, Figure 6C. The incorporation of $40 \% \mathrm{ZnO}$ larger nanoparticles leads to the increases in the pore size and hollow cavities in the films. These hollow cavities and the pores are partially filled by the small $\mathrm{ZnO}$ particles. The smaller $\mathrm{ZnO}$ nanoparticles, which can occupy some portion the hollow cavities form the intimate contact area between the particles and ITO glass substrate. Hence, the light scattering ability of ZL40 is higher than ZL0 and ZL10 caused by the variation in the ratio of large to smaller particle (Wang et al., 2006; Yu et al., 2011). Generally, when an optical beam is passed through the ITO glass and contact is made with the $\mathrm{ZnO}$ film electrodes, there are possibilities that the incident photon light gets reflected, scattered and transmitted within the film electrode. A part of incident light scattered within a $\mathrm{ZnO}$ films is returned to the surface is considered to be diffused reflectance (Lee et al., 2012). Noteworthy, that measuring the diffused reflectance spectrum is very essential to reveal the light scattering ability of samples. Based on the above two reasons largely sized $\mathrm{ZnO}$ nanoparticles are mixed for the enhancement of light scattering ability. Figure $6 \mathrm{~d}$ shows a large number of hollow cavities with greater pore size is present in ZL50 sample. The larger pore size of ZL50 sample enhances the light scattering ability and sensitizer adsorption into the $\mathrm{ZnO}$ film. This leads to a better conversion efficiency of cells (Kondo et al., 2008; Lee et al., 2012; Nelson \& Deng, 2008; Yu et al., 2010; Yu et al., 2011; Yu \& Chen, 2008). 
However, the specific surface area of film decreases because of the increasing number of large-sized $\mathrm{ZnO}$ particles. Even the contact area between the particles and ITO glass substrate was very poor. This is for the reason that the small $\mathrm{ZnO}$ particles were not sufficient enough to fill the number of hollow cavities. Normally, the decrease in a specific surface area with the poor contact area of the films retards the electron collection efficiency of ITO glass substrate thereby leading to poor performance. Further, it is experiential that large pore size and high porosity enhances the absorption of solar light and adsorption of sensitizer molecules into the $\mathrm{ZnO}$ film. However, ZL50 sample showed a very poor bonding with the ITO glass substrate. The poor bonding of particles with the ITO glass substrate decreases the electron collection efficiency of ITO glass substrate leading to poor photovoltaic performance (Nazeeruddin et al., 1993).

\section{Conclusions}

The synthesis of quinoline carboxylic acid oxime complex was carried out successfully. The adsorption of sensitizer onto the $\mathrm{ZnO}$ film slightly increases the photocurrent. The photocurrent increases due to the consequent decrease in the backward charge transfer from the $\mathrm{ZnO}$ to the electrolyte solution. A schematic illustration of $\mathrm{Ni}(\mathrm{II})-\left(\mathrm{Q}_{1}\right)_{2}$ complex adsorptions on different composition of small and large $\mathrm{ZnO}$ nanoparticles were performed. Our study reveals that the adsorption of the complex on $\mathrm{ZnO}$ films having only small pore sized particles show a less amount of photocurrent. The perfect combination of small and large $\mathrm{ZnO}$ nanoparticles can freely and fully adsorb the sensitizer molecules, which will increase the photocurrent of DSSC. In the experimental sample, the composition of the sample ZL40 is the optimized composition to obtain higher efficiency than other samples. The possible reason is the bonding between the electrode layer and the ITO glass substrate exerts and specific surface area thereby enhancing the photovoltaic performance. All the fabricated samples when used as cells showed very less efficiency which is due to the thickness of $\mathrm{ZnO}$ films $(<6 \mu \mathrm{m})$, and hence the complex was not able to absorb the wavelength above $>600 \mathrm{~nm}$. However, by increasing the thickness above $6 \mu \mathrm{m}$, good results can be achieved which can be further used as the source for conserving the energy.

\section{Acknowledgements}

The author wishes to acknowledge all who have contributed directly or indirectly in the present work.

\section{References}

Anderson, C., \& Bard, A. J. (1997). Improved Photocatalytic Activity and Characterization of Mixed TiO2/SiO2 and TiO2/A12O3 Materials. J. Phys. Chem. B, 101, 2611-2616.

Barbe, C. J., Arendse, F., Comte, P., Jirousek, M., Lenzmann, F., Shklover, V., \& Gratzel, M. (1997). Nanocrystalline Titanium Oxide Electrodes for Photovoltaic Applications. J. Am. Ceram. Soc, 80(12), 3157-3171.

Chappel, S., Grinis, L., Ofir, A., \& Zaban, A. (2005). Extending the Current Collector into the Nanoporous Matrix of Dye Sensitized Electrodes. J. Phys. Chem. B, 109, 1643-1647.

Chen, S. G., Chappel, S., Diamant, Y., \& Zaban, A. (2001). Preparation of Nb2O5 Coated TiO2 Nanoporous Electrodes and Their Application in Dye-Sensitized Solar Cells. Chem. Mater., 13, 4629-4634.

Dhas, V., Muduli, S., Agarkar, S., Rana, A., Hannoyer, B., Banerjee, R., \& Ogale, S. (2011). Enhanced DSSC performance with high surface area thin anatase $\mathrm{TiO} 2$ nanoleaves. Solar Energy, 85(6), 1213-1219. https://doi.org/10.1016/j.solener.2011.02.029 
Ferber, J., \& Luther, J. (1998). Computer simulations of light scattering and absorption in dye-sensitized solar cells. Solar Energy Materials and Solar Cells, 54, 265-275.

Grätzel, M. (2001). Photoelectrochemical cells. Nature, 414, 338-344.

Habibzadeh, S., Kazemi-Beydokhti, A., Khodadadi, A. A., Mortazavi, Y., Omanovic, S., \& Shariat-Niassar, M. (2010). Stability and thermal conductivity of nanofluids of tin dioxide synthesized via microwave-induced combustion route. Chemical Engineering Journal, 156(2), 471-478. https://doi.org/10.1016/j.cej.2009.11.007

Halaoui, L. I., Abrams, N. M., \& Mallouk, T. E. (2005). Increasing the Conversion Efficiency of Dye-Sensitized TiO2 Photoelectrochemical Cells by Coupling to Photonic Crystals. $J$. Phys. Chem. B, 109, 6334-6342.

Hjiri, M., Aida, M. S., Lemine, O. M., \& Mir, L. E. (2019). Study of defects in Li-doped ZnO thin films. Materials Science in Semiconductor Processing, 89, 149-153. https://doi.org/10.1016/j.mssp.2018.09.010

Hore, S., Nitz, P., Vetter, C., Prahl, C., Niggemann, M., \& Kern, R. (2005). Scattering spherical voids in nanocrystalline $\mathrm{TiO} 2$ - enhancement of efficiency in dye-sensitized solar cells. Chem Commun (Camb)(15), 2011-2013. https://doi.org/10.1039/b418658n

Ihara, M., Kanno, M., \& Inoue, S. (2010). Photoabsorption-enhanced dye-sensitized solar cell by using localized surface plasmon of silver nanoparticles modified with polymer. Physica E: Low-dimensional Systems and Nanostructures, 42(10), 2867-2871. https://doi.org/10.1016/j.physe.2010.04.001

Issa, Y. M., Hassib, H. B., \& Abdelaal, H. E. (2009). 1H NMR, 13C NMR and mass spectral studies of some Schiff bases derived from 3-amino-1,2,4-triazole. Spectrochim Acta A Mol Biomol Spectrosc, 74(4), 902-910. https://doi.org/10.1016/j.saa.2009.08.042

Jo, H., Yang, J.-H., Choi, S.-W., Park, J., Song, E. J., Shin, M., Ahn, J.-H., \& Kwon, J.-D. (2019). Highly transparent and conductive oxide-metal-oxide electrodes optimized at the percolation thickness of AgOx for transparent silicon thin-film solar cells. Solar Energy Materials and Solar Cells, 202, 110131. https://doi.org/10.1016/j.solmat.2019.110131

Kambe, S., Murakoshi, K., Kitamura, T., Wada, Y., Yanagida, S., Kominami, H., \& Kera, Y. (2000). Mesoporous electrodes having tight agglomeration of single-phase anatase TiO2 nanocrystallites: Application to dye-sensitized solar cells. Solar Energy Materials \& Solar Cells, 61, 427-441.

Kashyout, A. B., Soliman, M., \& Fathy, M. (2010). Effect of preparation parameters on the properties of TiO2 nanoparticles for dye sensitized solar cells. Renewable Energy, 35(12), 2914-2920. https://doi.org/10.1016/j.renene.2010.04.035

Katoh, R., Furube, A., Hara, K., Murata, S., Sugihara, H., Arakawa, H., \& Tachiya, M. (2002). Efficiencies of Electron Injection from Excited Sensitizer Dyes to Nanocrystalline ZnO Films as Studied by Near-IR Optical Absorption of Injected Electrons. J. Phys. Chem. B, 106, 12957-12964.

Keis, K., Magnusson, E., Lindstrom, H., Lindquist, S.-E., \& Hagfeldt, A. (2002). A 5\% efficient photoelectrochemical solar cell based on nanostructured $\mathrm{ZnO}$ electrodes. Solar Energy Materials \& Solar Cells, 73, 51-58.

Kimtys, L. L., \& Balevicius, V. J. (1979). Self Association of Carboxalic acids as studied by 1 HNMR spectroscopy. Advances in Molecular Relaxation and Interaction Processes, 15, $151-1161$. 
Kondo, Y., Yoshikawa, H., Awaga, K., Murayama, M., Mori, T., Sunada, K., Bandow, S., \& Iijima, S. (2008). Preparation, Photocatalytic Activities, and Dye-Sensitized Solar-Cell Performance of Submicron-Scale TiO2 Hollow Spheres. Langmuir, 24, 547-550.

Kumara, G. R. R. A., Tennakone, K., Kottegoda, I. R. M., KMBandaranayake, P., Konno, A., Okuya, M., Kaneko, S., \& Murakami, K. (2003). Efficient dye-sensitized photoelectrochemical cells made from nanocrystalline tin(IV) oxide-zinc oxide composite films. Semicond. Sci. Technol., 18, 312-318.

Lee, S.-W., Ahn, K.-S., Zhu, K., Neale, N. R., \& Frank, A. J. (2012). Effects of TiCl4 Treatment of Nanoporous TiO2 Films on Morphology, Light Harvesting, and ChargeCarrier Dynamics in Dye-Sensitized Solar Cells. The Journal of Physical Chemistry C, 116(40), 21285-21290. https://doi.org/10.1021/jp3079887

Lee, S., Cho, I.-S., Lee, J. H., Kim, D. H., Kim, D. W., Kim, J. Y., Shin, H., Lee, J.-K., Jung, H. S., Park, N.-G., Kim, K., Ko, M. J., \& Hong, K. S. (2010). Two-Step Sol-Gel MethodBased TiO2Nanoparticles with Uniform Morphology and Size for Efficient Photo-Energy Conversion Devices. Chemistry of Materials, 22(6), 1958-1965. https://doi.org/10.1021/cm902842k

Li, W., Lv, F., Shu, T., Tan, X., Jiang, L., Xiao, T., \& Xiang, P. (2019). Improving the performance of FTO conducting glass by $\mathrm{SiO} 2$ and $\mathrm{ZnO}$ anti-reflection films for dyesensitized solar cells. Materials Letters, 243, 108-111. https://doi.org/10.1016/j.matlet.2019.01.158

Liao, J.-Y., He, J.-W., Xu, H., Kuang, D.-B., \& Su, C.-Y. (2012). Effect of TiO2 morphology on photovoltaic performance of dye-sensitized solar cells: nanoparticles, nanofibers, hierarchical spheres and ellipsoid spheres. Journal of Materials Chemistry, 22(16), 7910. https://doi.org/10.1039/c2jm16148f

Lu, J., Liang, K., Xu, C., Wang, X., Ouyang, H., Huang, J., \& Feng, L. (2019). Humidity sensor based on heterogeneous $\mathrm{CoTiO} 3 / \mathrm{TiO} 2$ film with vertically aligned nanocrystalline structure. Vacuum, 163, 292-300. https://doi.org/10.1016/j.vacuum.2019.02.027

Makhonina, E. V., Maslennikova, L. S., Volkov, V. V., Medvedeva, A. E., Rumyantsev, A. M., Koshtyal, Y. M., Maximov, M. Y., Pervov, V. S., \& Eremenko, I. L. (2019). Li-rich and Ni-rich transition metal oxides: Coating and core-shell structures. Applied Surface Science, 474, 25-33. https://doi.org/10.1016/j.apsusc.2018.07.159

Muduli, S., Game, O., Dhas, V., Vijayamohanan, K., Bogle, K. A., Valanoor, N., \& Ogale, S. B. (2012). TiO2-Au plasmonic nanocomposite for enhanced dye-sensitized solar cell (DSSC) performance. Solar Energy, 86(5), 1428-1434. https://doi.org/10.1016/j.solener.2012.02.002

Nakade, S., Kubo, W., Saito, Kanzaki, T., Kitamura, T., Wada, Y., \& Yanagida, S. (2003). Influence of Measurement Conditions on Electron Diffusion in Nanoporous TiO2 Films: Effects of Bias Light and Dye Adsorption. J. Phys. Chem. B, 107, 14244-14248.

Nazeeruddin, M. K., \& Grätzel, M. (2001). Separation of linkage isomers of trithiocyanato $(4,4,4$-tricarboxy-2,2,6,2-terpyridine)ruthenium(II) by $\mathrm{pH}$-titration method and their application in nanocrystalline TiO2-based solar cells. Journal of Photochemistry and Photobiology A: Chemistry, 145, 79-86.

Nazeeruddin, M. K., Kay, A., Rodicio, Humpbry-Baker, R., Miiller, E., Liska, P., Vlachopoulos, N., \& Gratzel', M. (1993). Conversion of Light to Electricity by cis-XzBis( 2,2'-bipyridyl-4,4'-dicarboxylate)ruthenium( 11) Charge-Transfer Sensitizers (X = C1-, 
Br-, I-, CN-, and SCN-) on Nanocrystalline Ti02 Electrodes. J. Am. Chem. So, 113, 63826390.

Nazeeruddin, M. K., Pechy, P., Renouard, T., Zakeeruddin, S. M., Humphry-Baker, R., Comte, P., Liska, P., Cevey, L., Costa, E., Shklover, V., Spiccia, L., Deacon, G. B., Bignozzi, C. A., \& Gratzel, M. (2001). Engineering of Efficient Panchromatic Sensitizers for Nanocrystalline TiO2-Based Solar Cells. J. Am. Chem. Soc., 123, 1613-1624.

Nelson, K., \& Deng, Y. (2008). Enhanced Light Scattering from Hollow Polycrystalline TiO2 Particles in a Cellulose Matrix. Langmuir, 24, 975-982.

Ni, M., Leung, M. K. H., Leung, D. Y. C., \& Sumathy, K. (2006). An analytical study of the porosity effect on dye-sensitized solar cell performance. Solar Energy Materials and Solar Cells, 90(9), 1331-1344. https://doi.org/10.1016/j.solmat.2005.08.006

[Record \#316 is using a reference type undefined in this output style.]

Nishimura, S., Abrams, N., Lewis, B. A., Halaoui, L. I., Mallouk, T. E., Benkstein, K. D., Lagemaat, J. v. d., \& Frank|, A. J. (2003). Standing Wave Enhancement of Red Absorbance and Photocurrent in Dye-Sensitized Titanium Dioxide Photoelectrodes Coupled to Photonic Crystals. J. Am. Chem. Soc., 125, 6306-6310.

O'Reagen, B., \& Gratzel, M. (1991). A low-cost, high efficiency solar cell based on dye sensitized colloidal TiO2 films. Nature, 353, 737-.

Ocakoglu, K., Yakuphanoglu, F., Durrant, J. R., \& Icli, S. (2008). The effect of temperature on the charge transport and transient absorption properties of K27 sensitized DSSC. Solar Energy Materials and Solar Cells, 92(9), 1047-1053. https://doi.org/10.1016/j.solmat.2008.03.006

Palomares, E., Clifford, J. N., Haque, S. A., Lutz, T., \& Durrant, J. R. (2002). Control of Charge Recombination Dynamics in Dye Sensitized Solar Cells by the Use of Conformally Deposited Metal Oxide Blocking Layers. J. Am. Chem. Soc., 125, 475-482.

Park, J. W., Kang, B. H., \& Kim, H. J. (2019). A Review of Low-Temperature SolutionProcessed Metal Oxide Thin-Film Transistors for Flexible Electronics. Advanced Functional Materials, 30(20), 1904632. https://doi.org/10.1002/adfm.201904632

Rothenberger, G., Comte, P., \& tzel, M. G. (1999). A contribution to the optical design of dye-sensitized nanocrystalline solar cells. Solar Energy Materials \& Solar Cells, 58, 321336.

Sant, P. A., \& Kamat, P. V. (2002). Interparticle electron transfer between size-quantized $\mathrm{CdS}$ and $\mathrm{TiO} 2$ semiconductor nanoclustersDedicated to Professor Frank Wilkinson on the occasion of his retirement. Physical Chemistry Chemical Physics, 4(2), 198-203. https://doi.org/10.1039/b107544f

So, W.-W., Kim, K.-J., Lee, J.-K., \& Moon, S.-J. (2004). Manufacture of Dye Sensitized Solar Cell Using Titania Sol Prepared at Room Temperature by the Sol-Gel Method. Japanese Journal of Applied Physics, 43(3), 1231-1235. https://doi.org/10.1143/jjap.43.1231

Suttiponparnit, K., Jiang, J., Sahu, M., Suvachittanont, S., Charinpanitkul, T., \& Biswas, P. (2011). Role of Surface Area, Primary Particle Size, and Crystal Phase on Titanium Dioxide Nanoparticle Dispersion Properties. Nanoscale Res Lett, 1-8. 
Tennakone, K., Kumara, G. R. R. A., Kottegoda, I. R. M., \& Perera, V. P. S. (1999). An efficient dye-sensitized photoelectrochemical solar cell made from oxides of tin and zinc. Chem. Commun, 15-16.

Usami, A. (1997). Theoretical study of application of multiple scattering of light to a dyesensitized nanocrystalline photoelectrochemical cell. Chemical Physics Letters, 277, 105108.

Usami, A. (1999). Rigorous solutions of light scattering of neighboring TiO2 particles in nanocrystalline "lms. Solar Energy Materials \& Solar Cells, 159, 163-166.

Wang, B., Zhang, M., Cui, X., Wang, Z., Rager, M., Yang, Y., ZhigangZou, Wang, Z. L., \& Lin, Z. (2020). Unconventional Route to Oxygen Vacancies-Enabled Highly Efficient Electron Extraction and Transport in Perovskite Solar Cell. Angewandte Chemie. https://doi.org/10.1002/anie.201910471

10.1002/ange.201910471

Wang, Q., Ito, S., Gratzel, M., Fabregat-Santiago, F., Mora-Sero, I. n., Bisquert, J., Bessho, T., \& Imai, H. (2006). Characteristics of High Efficiency Dye-Sensitized Solar Cells. J. Phys. Chem. B, 110, 25210-25221.

Wang, Z.-S., Kawauchi, H., Kashima, T., \& Arakawa, H. (2004). Significant influence of TiO2 photoelectrode morphology on the energy conversion efficiency of N719 dyesensitized solar cell. Coordination Chemistry Reviews, 248(13-14), 1381-1389. https://doi.org/10.1016/j.ccr.2004.03.006

Wen, X., Nowak-Krol, A., Nagler, O., Kraus, F., Zhu, N., Zheng, N., Muller, M., Schmidt, D., Xie, Z., \& Wurthner, F. (2019). Tetrahydroxy-Perylene Bisimide Embedded in a Zinc Oxide Thin Film as an Electron-Transporting Layer for High-Performance Non-Fullerene Organic Solar Cells. Angew Chem Int Ed Engl, 58(37), 13051-13055. https://doi.org/10.1002/anie.201907467

Wenger, B., Gratzel, M., \& Moser, J.-E. (2005). Rationale for Kinetic Heterogeneity of Ultrafast Light-Induced Electron Transfer from $\mathrm{Ru}(\mathrm{II})$ Complex Sensitizers to Nanocrystalline TiO2. J. Am. Chem. Soc., 127, 12150-12151.

Yu, J., Fan, J., \& Zhao, L. (2010). Dye-sensitized solar cells based on hollow anatase TiO2 spheres prepared by self-transformation method. Electrochimica Acta, 55(3), 597-602. https://doi.org/10.1016/j.electacta.2009.09.021

Yu, J., Li, Q., \& Shu, Z. (2011). Dye-sensitized solar cells based on double-layered TiO2 composite films and enhanced photovoltaic performance. Electrochimica Acta, 56(18), 6293-6298. https://doi.org/10.1016/j.electacta.2011.05.045

Yu, K., \& Chen, J. (2008). Enhancing Solar Cell Efficiencies through 1-D Nanostructures. Nanoscale Res Lett, 4(1), 1-10. https://doi.org/10.1007/s11671-008-9200-y

Zhang, Q., Myers, D., Lan, J., Jenekhe, S. A., \& Cao, G. (2012). Applications of light scattering in dye-sensitized solar cells. Phys Chem Chem Phys, 14(43), 14982-14998. https://doi.org/10.1039/c2cp43089d

Zhu, T., Shen, W., Wang, X., Song, Y.-F., \& Wang, W. (2019). Paramagnetic CoS2@MoS2 core-shell composites coated by reduced graphene oxide as broadband and tunable highperformance microwave absorbers. Chemical Engineering Journal, 378, 122159. https://doi.org/10.1016/j.cej.2019.122159 